\title{
Control of oocyte growth and maturation by follicular cells and molecules present in follicular fluid. A review
}

\author{
Marc-Antoine Driancourt*, Blandine Thuel \\ Inra-URA CNRS 1291, PRMD, 37380 Nouzilly, France
}

(Received 26 March 1998; accepted 26 June 1998)

\begin{abstract}
The aim of this review is to summarize the interactions between the oocyte and its surrounding granulosa cells which are involved in the control of oocyte growth or apoptosis as well as those playing a key role in the ability of the oocyte to undergo nuclear (resumption as meiosis to reach the MII stage) or cytoplasmic maturation (ability to fertilize and develop to the blastocyst stage). The respective roles of the oocyte and of the granulosa cells in controlling the initiation of growth are poorly understood. During the preantral follicular stage when most oocyte growth is achieved, a local regulation appears to be in operation involving growth factors such as fibroblast growth factor (FGF) or epidermal growth factor/transforming growth factor $\alpha$ (EGF/TGF $\alpha)$, together with two proteins (c-kit present on the oocyte's membrane and its ligand KL produced by granulosa cells). Insitu techniques used to detect apoptosis demonstrate apoptotic oocytes in the reserves of primordial follicles but seldom within preantral follicles (because it is too fast?). Proteins involved in cell death (bax) or cell survival (bcl2) are present in oocytes as well as compounds (TNF $\alpha$, Fas) involved in the initiation of apoptosis. However, the molecular and cellular mechanisms triggering oocyte apoptosis are not fully clarified. Three approaches have been used to identify compounds which are relevant to the oocyte's nuclear or cytoplasmic maturation. a) Correlation between amounts of specific compounds in follicular fluid or within follicle cells and the oocyte's ability to mature. b) Analysis of the consequences of pharmacological disruption of mechanisms such as steroidogenesis on oocyte maturation. c) Analysis of the consequences of addition of graded amounts of specific compounds on oocyte maturation in defined media. Factors playing a key role in stimulating nuclear maturation appear to be epidermal growth factor (EGF) and the inhibin (cattle)/activin (rodents) family, while testosterone has an inhibitory effect. Cytoplasmic maturation of the oocyte appears to be stimulated by oestradiol, EGF and inhibin. (OInra/Elsevier, Paris
\end{abstract}

oocyte / granulosa / maturation / apoptosis / growth / growth factors

Résumé - Interactions entre l'ovocyte et les cellules folliculaires. Conséquences pour la croissance, l'apoptose et la maturation ovocytaire. L'objectif de cette revue est d'analyser l'impact des

* Correspondence and reprints

E-mail: driancou@tours.inra.fr 
interactions cellules somatiques-cellules germinales dans la croissance ou l'apoptose ovocytaire puis dans l'acquisition par l'ovocyte de l'aptitude à réaliser séquentiellement sa maturation nucléaire (reprise de la méiose) et sa maturation cytoplasmique (permettant la fécondation et le développement embryonnaire précoce). L'importance respective de l'ovocyte et des cellules de granulosa pour l'initiation de la croissance est mal connue. En revanche, au cours de la période préantrale où l'ovocyte effectue la plus grande partie de son accroissement en taille, des régulations locales impliquant des facteurs de croissance (FGF : fibroblast growth factor, EGF/TGF $\alpha$ : epidermal-transforming growth factor $\alpha$ ) et un couple de protéines (c-kit présent sur l'ovocyte et son ligand KL produit par la granulosa) paraissent jouer un rôle clé. L'apoptose ovocytaire est principalement visualisée par les techniques in situ dans les réserves de follicules primordiaux. Elle est rare dans les follicules préantraux (parce qu'elle est rapide ?). Les protéines (bax, bcl2) impliquées dans la survie ou la mort cellulaire sont présentes dans les ovocytes, tout comme des composés (TNF $\alpha$, Fas) impliqués dans l'initiation de l'apoptose. Les mécanismes cellulaires et moléculaires contrôlant l'apoptose ovocytaire sont encore inconnus. Trois types d'approches ont été employés pour identifier les composés impliqués dans l'acquisition par l'ovocyte de son aptitude à faire maturation nucléaire puis maturation cytoplasmique. a) L'étude des corrélations entre cette aptitude et les quantités de composés spécifiques présents dans le follicule, le cumulus ou le liquide folliculaire. b) L'étude des conséquences du blocage de certaines fonctions (stéroïdogenèse en particulier) par des approches pharmacologiques sur la maturation ovocytaire. c) L'étude de l'effet de la supplémentation de milieux définis utilisés lors de la maturation in vitro sur la maturation ovocytaire. Les composés affectant la maturation nucléaire paraissent être l'epidermal growth factor (EGF), la famille inhibine (bovin)/activine (rongeurs) qui stimulent la maturation nucléaire alors que la testostérone a un rôle inhibiteur. Les principaux composés affectant la maturation cytoplasmique sont l'œstradiol, l'EGF et l'inhibine qui la stimulent. (O) Inra/Elsevier, Paris

ovocyte / granulosa / maturation / apoptose / croissance

\section{INTRODUCTION}

Folliculogenesis in mammalian species is a highly selective process. Only a very small proportion of the follicles $(\cong 0.1 \%$ ) survive apoptosis, which takes place in the stores of primordial follicles (rodents: Byskov [9]; sheep: Driancourt et al. [29]; human: Gougeon et al. [42]) as well as in preantral follicles (sheep: Driancourt et al. [29]; cattle: Schotanus et al. [86]). At these two stages, the oocyte is the first cell within the follicle to be affected by apoptosis. Whether oocyte apoptosis is related to oocyte defects or to an improper dialogue between the oocyte and its surrounding granulosa cells remains unclear. If the oocyte succeeds in evading apoptosis, it will grow actively while the follicle is at the preantral stage, since when antrum forms, the oocyte has reached about $85 \%$ of its final size. During the initial section of this review, the local interactions between the oocyte and its surrounding cells involved in the control of growth and apoptosis will be summarized.
Once antrum formation occurs within the follicle (at about $0.2 \mathrm{~mm}$ in diameter), changes in oocyte size are limited. However, functional changes which play a key role in oocyte maturation (nuclear and cytoplasmic) do occur. During nuclear maturation, meiosis resumes so that the oocyte, when ovulated, has reached the metaphase II stage. During cytoplasmic maturation, complex changes occur in the oocyte which are not fully understood. Changes in cortical granule distribution, alterations in the repartition of cytoplasmic organelles, accumulation or destruction of specific mRNAs or proteins have been observed. All these changes are of key importance in generating good quality oocytes (i.e. oocytes capable of producing a live young following fertilization and development).

In all mammalian species, there are strong links between follicular growth and oocyte maturation. For example, in cattle only $1.4 \%$ of the oocytes originating from follicles smaller than $1 \mathrm{~mm}$ in diameter have the ability to reach metaphase II [38]. This 


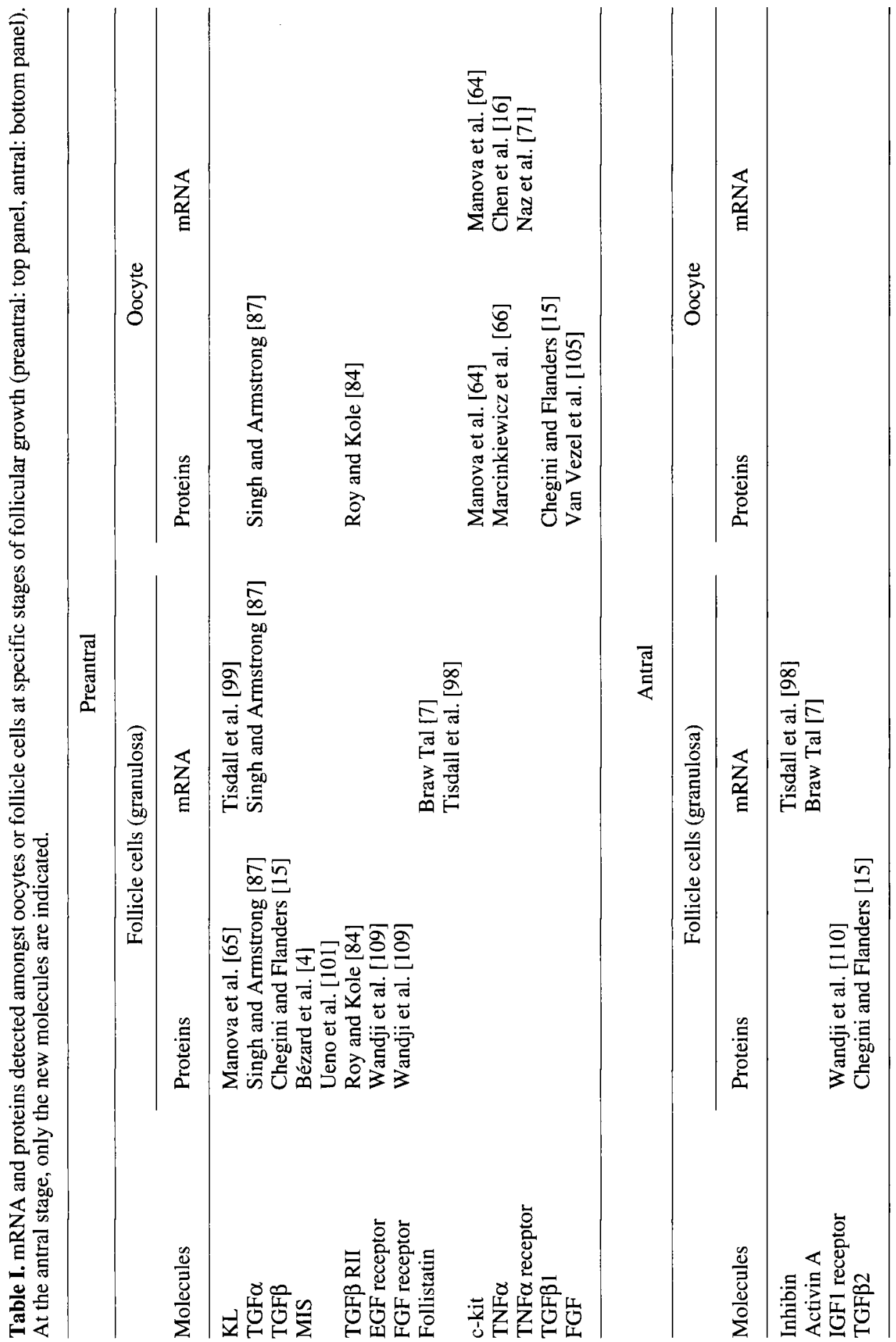


proportion is at least 10 times lower than the level reached when oocytes are obtained from follicles 1 to $3 \mathrm{~mm}$ in diameter. These data were extended by Fair et al. [34] who showed that follicles $2.5 \mathrm{~mm}$ in diameter (and an oocyte diameter of 110-120 $\mu \mathrm{m}$ ) represent a threshold at which the oocyte becomes capable of completing meiosis to metaphase II. It is only when the oocyte has acquired the ability to resume meiosis that it begins to be capable of undergoing cytoplasmic maturation. For example, in cattle Pavlok et al. [77] showed that following in vitro maturation (IVM) and fertilization (IVF), oocytes obtained from follicles smaller than $2 \mathrm{~mm}$ in diameter could not reach the blastocyst stage. The proportion of oocytes developing to the blastocyst stage increased from 21 to $28 \%$ when the oocytes were obtained from follicles $2-4 \mathrm{~mm}$ or $4-8 \mathrm{~mm}$ in diameter. The superiority in terms of ability to develop to the blastocyst stage of oocytes originating from large follicles was confirmed by Lonergan et al. [61]. Furthermore, the observation that zygotes recovered after in-vivo maturation and fertilization (i.e. ovulated from follicles $12-16 \mathrm{~mm}$ in diameter) develop better in culture than those produced totally in vitro [68] also strongly supports the hypothesis that functional interactions between the maturing follicle and the oocyte take place.

Good evidence exists suggesting that the mechanisms involved in the control of oocyte growth and those involved in nuclear or cytoplasmic maturation are distinct. Support for this claim was obtained by Canipari et al. [11] who demonstrated that small oocytes at different stages of growth cultured on a feeder layer of fibroblasts do not grow but have the ability to resume meiosis and reach metaphase II at a time which corresponds strictly to the in-vivo situation. Furthermore Eppig and O'Brien [33], in an elegant study, demonstrated that 22-day-old oocytes obtained from 6-, 8- and 12-dayold mice (and cultured in vitro for 16,14 and 10 days, respectively), despite having the same size, had vastly different abilities to cleave to the blastocyst stage. Hence, in the final part of this review, the specific compounds produced by follicle cells which are relevant to nuclear and cytoplasmic maturation will be identified and their role discussed.

\section{REGULATION OF FOLLICLE FUNCTION CHANGES THROUGHOUT FOLLICULAR GROWTH}

Little information is available on the control of follicle function in follicles which grow from the reserves of primordial follicles and in preantral follicles. Data obtained in models where gonadotrophin concentrations are minimal (hypophysectomy: Dufour et al. [32], in vitro culture in the absence of gonadotrophins: Wandji et al. [111], knock out of the FSH $\beta$ gene: Kumar et al. [56]) suggest that local (autocrine and paracrine) regulation is of key importance at this stage. Proteins, growth factors and their receptors which are expressed and/or present in the oocyte or in granulosa cells at the preantral stage are summarized in table I. Paracrine signalling between the oocyte and granulosa cells could occur for FGF (fibroblast growth factor) and EGF (epidermal growth factor) which are expressed in oocytes and whose receptors are present in granulosa cells. This conclusion is also valid for c-kit which is present on the oocyte, while its ligand $(\mathrm{KL})$ is produced by granulosa cells.

Additional regulatory factors which may become functional when follicles form an antrum are insulin-like growth factors (IGF1/IGF2) owing to the appearance of IGF receptors on granulosa cells at this stage. Their importance is shown by the observation that in IGF1 null mice, there are no antral follicles [3]. In addition, inhibin and activin become detectable at this stage (sheep: Tisdall et al. [98]; primates: Gougeon [41]). This is summarized in table I. 
The main processes involved in the growth and differentiation of the ovulatory follicle throughout the gonadotrophin dependent phase (starting at $2 \mathrm{~mm}$ in sheep, human and $3 \mathrm{~mm}$ in cattle) are summarized in figure 1. Detailed information can be found in other reviews $[28,41]$. During the recruitment to selection phase (from 2 to $4 \mathrm{~mm}$ and 2 to $8 \mathrm{~mm}$ in sheep and human, respectively), the key gonadotrophin is FSH which induces aromatase activity in granulosa cells. This FSH action is potentialized by an autocrine action of activin produced by granulosa cells. During the dominance phase (from 4 and $8 \mathrm{~mm}$ to ovulatory size in sheep and human, respectively), LH becomes of key importance in stimulation of thecal steroidogenesis. This LH action is further increased by a paracrine action of the high amounts of inhibin produced by granulosa cells as well as by the high bio-availability of IGFs (owing to the reduced amounts of its binding proteins). The high androgen output by theca cells together with the high aromatase activity in the granulosa cells differentiated earlier during the follicular phase, results in a high oestradiol output by the preovulatory follicle.

\section{THE CLOSEST FOLLICULAR ENVIRONMENT FOR THE OOCYTE: THE CUMULUS CELLS}

Cumulus cells have features which are different from the granulosa cells which are further away from the oocyte. The main differences are:

- the absence of expression of the mRNA coding for the LH receptor [79]. As a consequence, the number of $\mathrm{LH}$ receptors per cumulus cell is markedly reduced compared to that observed on granulosa cells [14];

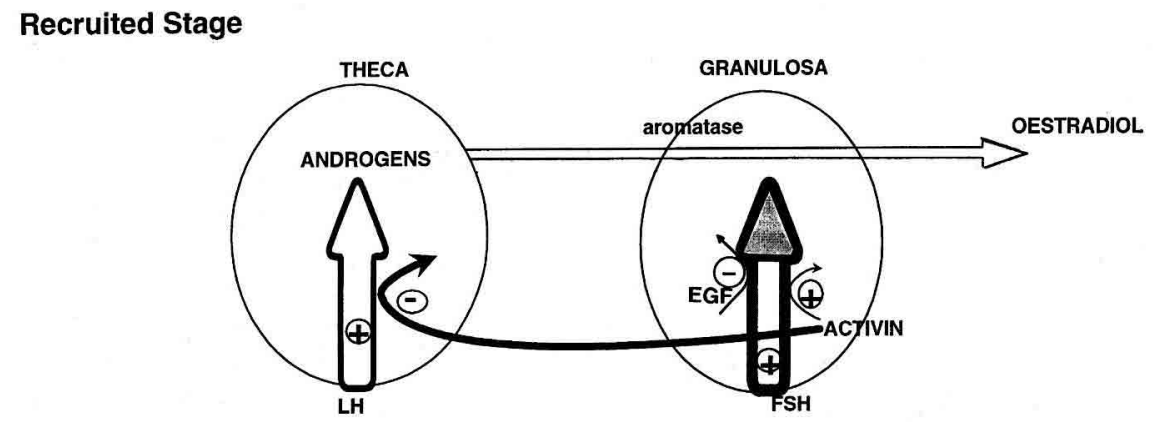

Dominant Stage

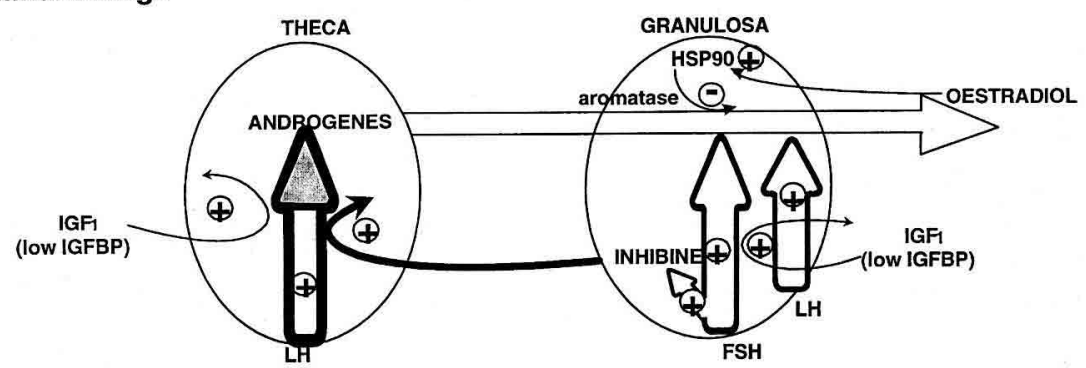

Figure 1. Regulation of follicular maturation by both endocrine and local mechanisms. The top of the figure describes the follicle at the recruited stage while the bottom describes it during its dominant stage. During the recruited stage, FSH is the main gonadotrophin and activin the main locally acting compound. During the dominant stage, LH is the main gonadotrophin and IGF1 together with inhibin are the main locally acting compounds. 
- a markedly reduced ability to produce steroids; cumulus cells contain reduced amounts of $3 \beta$ hydroxysteroid dehydrogenase (involved in progesterone production) [120] and very low amounts of aromatase [96, 119];

- interestingly, higher amounts of the mRNA coding for most of the members of the inhibin family ( $\alpha$ inhibin, follistatin, MIS) have been reported in cumulus cells [7, 102]. Whether the amounts of these proteins are also higher within cumulus cells has not been established. Activin, in contrast, does not appear to be preferentially located to cumulus cells at least in sheep;

- a more active proliferation of the cells [47]. This increased ability of cumulus cells to divide may be a consequence of their more limited differentiation;

- a lower sensitivity to atresia. In atretic follicles, cumulus cells are always the last ones to enter atresia. Pycnotic bodies amongst cumulus cells start to appear when atresia is widespread in the rest of the follicle [30].

It is not yet clear whether this altered environment is important for the proper development of the oocyte (which is linked to cumulus cells by numerous gap junctions) or if it is the consequence of the presence of the oocyte $[106,107]$.

\section{THE OOCYTE CUMULUS COMPLEX FLOATS IN FOLLICULAR FLUID}

Follicular fluid is a complex mixture of serum proteins and proteins secreted by follicle cells. Transit of proteins through the basal membrane appears to be related to molecular weight and charge and possibly protein conformation. Following two dimensional electrophoresis of newly synthesized proteins (S35 incorporated) by intact follicles, 100-150 spots are observed of which $95 \%$ are present in follicular fluid and are transferred through the basal membrane towards incubation medium [31]. One protein $(52 \mathrm{kDa})$ is stored in follicular fluid and not secreted outside the follicle and three proteins $(30,31$ and $90 \mathrm{kDa})$ are more abundant in follicular fluid than outside the follicle. However, none of these newly synthesized proteins can be visualized on silver stained gels of follicular fluid. This is because most of its proteins originate from serum. Hence compounds originating in serum as well as ovary specific compounds are candidates for affecting oocyte maturation.

\section{THE OOCYTE IS SENSITIVE TO FOLLICULAR SECRETIONS}

Follicular cells (granulosa and theca) produce large amounts of steroids and growth factors or proteins [41]. Most of them are at least partly stored in follicular fluid.

As regards steroids, Wu et al. [115] have demonstrated that the human oocyte expresses mRNA for the oestrogen receptor ( $\alpha$ type). This suggests that oestradiol may directly act on the oocyte. This finding has not, however, been confirmed in farm animals either by RT-PCR or immunohistochemistry. There is no information, at present, on expression or presence of the $\beta$ type oestradiol receptor or of the androgen receptor on oocytes of mammalian species.

With respect to growth factors, the oocyte appears to bear receptors for EGF/TGF $\alpha$ $[17,81]$, for IGF1 and IGF2 [95] and PDGF [113]. There has been no demonstration that receptors for other growth factors are present (TGF $\beta$, MIS, FGF) despite observations that these compounds (TGFß, MIS) can affect function of denuded oocytes $[35,93]$.

Finally data demonstrating the presence of activin receptors on the oocyte have been presented in rats [10] and cattle [50]. This is in good agreement with the accumulation of ${ }^{125} \mathrm{I}$ activin along the zona pellucida after in vivo injection [114]. 


\section{AUTOCRINE AND PARACRINE REGULATION BETWEEN OOCYTE AND GRANULOSA CELLS INVOLVED IN THE CONTROL OF OOCYTE GROWTH}

Three sequential phases of growth can be visualized when oocyte diameter is plotted against follicle diameter: a) initiation of oocyte enlargement; b) rapid oocyte growth up to antrum formation in the follicle; c) slow growth between this stage and ovulation. Possible regulatory mechanisms for each specific phase are detailed below by addressing three specific questions.

1) What triggers initiation of oocyte growth?

Whether initiation of oocyte growth is caused by compound(s) originating from the oocyte or from the surrounding granulosa cells has not yet been clarified. This issue is complicated by the existence, at least in rodents, of different reserves of primordial follicles, each containing oocytes of different diameters and surrounded by variable numbers of granulosa cells [67]. When follicles present 10-15 granulosa cells in the largest cross section, oocyte nucleolar RNA-polymerase increases [60] suggesting that oocyte growth is initiated. However, the relationships between granulosa cell proliferation and activation of nucleolar RNA polymerase in the oocyte have not been clarified. On the one hand, granulosa cell proliferation may increase the amounts of compounds (such as kit ligand, $\mathrm{KL}$ ) stimulating oocyte growth [76] while on the other, oocyte growth may affect granulosa cell proliferation [106].

Key compounds for growth initiation are c-kit, a receptor present on the oocyte membrane at the primordial stage and its ligand (KL) produced by granulosa cells. Strong evidence supporting this claim has been obtained from two lines of mice ( $\mathrm{St}^{\mathrm{t}}$ and $\mathrm{St}^{\mathrm{pan}}$ ) which harbour mutations in the KL gene. In these lines few follicles initiate growth despite numerous primordial fol- licles being present in the ovaries $[49,57]$. The role (if any) of other compounds present in the oocyte (myc oncoprotein, retinoblastoma protein; Li et al. [59]; Bukowsky et al. [8]) or in granulosa cells of resting follicles (WT1 [48]) remains to be clarified. New genes involved in growth initiation may be identified from two lines of sheep (Cambridge, Inverdale) where major genes are segregating $[22,43]$ and where part of the ewes are sterile owing to the lack of synchrony between oocyte growth (which occurs) and granulosa cell proliferation (which is absent) in Cambridge ewes or owing to absence of initiation of follicular and oocyte growth in Inverdale ewes [23].

2) Which compounds are responsible for the rapid growth of the oocyte during the preantral stage?

There is solid evidence for involvement of three main factors (c-kit + KL, EGF and FGF) in oocyte enlargement, during the rapid growth phase. The key mechanism again appears to be the interactions between c-kit and KL. In the elegant study of Packer et al. [76], a stimulatory effect of graded doses of KL was observed on oocyte growth. Furthermore, incubation of oocytes on monolayers of granulosa cells increased the amounts of mRNA coding for KL [76]. This loop whereby the oocyte stimulates the production of KL and where KL stimulates oocyte growth is of utmost importance at this stage. This is further supported by the observation [117] that blocking the c-kit$\mathrm{KL}$ interaction in vivo completely abolishes preantral oocyte and follicular growth.

Fibroblast growth factor (FGF) which is present in oocytes of preantral follicles [105], for which receptors are present on preantral granulosa cells [109] and which is mitogenic for granulosa cells [72] may also be operating to promote growth at this stage by a paracrine signalling between the oocyte and the granulosa cells.

The same reasoning could apply to epidermal growth factor (EGF)/transforming growth factor $\alpha$ (TGF $\alpha$ ) which is present 
in oocytes [87], for which receptors are present in granulosa cells [109] and which also stimulates granulosa cell replication [40]. The FGF and EGF stimulated increase in the number of granulosa cells will increase the amounts of KL produced by this layer, which will in turn stimulate further oocyte growth. The cAMP produced after binding of FSH to its receptors which are present on granulosa cells at the preantral stage may also operate in a similar way [76]. Interestingly, a novel regulator of this phase was identified [24] when it was shown that follicular growth was blocked during the preantral phase in GDF9 (a member of the TGFB superfamily) knock out mice.

3) Why does oocyte growth ceases when antrum forms?

This growth arrest could be explained either by the appearance of compounds which inhibit oocyte growth (for compounds appearing at the antral stage, see figure $1 b$ ) or by the disappearance of growth promoting compounds. While there is no data supporting an effect of insulin-like growth factors (IGF1/IGF2), TGF $\beta 2$, inhibin or activin A on oocyte growth, there is good evidence [70] that the cessation of oocyte growth at the antral stage is associated with the cessation of KL expression in the cumulus cells surrounding the oocyte. This block in the c-kit-KL stimulatory loop may explain the slow pace of growth noted in oocytes throughout the antral phase.

\section{AUTOCRINE AND PARACRINE REGULATIONS BETWEEN THE OOCYTE AND GRANULOSA CELLS INVOLVEDINTHE CONTROL OF OOCYTE APOPTOSIS}

Signals that lead to the induction of apoptosis include oxydative stress, the withdrawal of extracellular signals (specific growth factors) as well as the stimulation of some cell surface molecules such as the TNF $\alpha$ receptor or the Fas/Apo1 molecule. A num- ber of excellent reviews are available on the general mechanisms involved $[18,108]$. Briefly, induction of apoptosis is followed by ceramide generation, which will ultimately activate caspases (CPP 32) which are proteases able to induce nuclear DNA fragmentation, plasma membrane (blebbing) and mitochondrial changes (alterations in mitochondrial membrane potential). Cell death $(\mathrm{Bax}, \mathrm{Bcl} \times$ short) or cell survival $(\mathrm{Bcl} 2, \mathrm{Bcl} \times$ long) proteins modulate caspase activation.

All the apoptotic machinery is present in oocytes. TNF $\alpha$ receptor is present on the surface of oocytes [71] as is Fas/Apo1 [112]. $\mathrm{Bcl} 2$ and Bax can be identified by immunohistochemistry within oocytes (K. Reynaud and M.A. Driancourt, unpublished data). That both compounds are involved in oocyte apoptosis is shown by the observations that genetic ablation of $\mathrm{Bcl} 2$ and $\mathrm{Bax}$ expression $[82,97]$ markedly alter the number of primordial follicles present in postnatal ovaries. A similar conclusion also stands for caspases since caspase 2 knockout mice exhibit an increased number of primordial follicles in post-natal ovaries [97]. While the pathways used for the development of the apoptotic process are relatively clear, the way in which oocytes and granulosa cells interact to escape or promote apoptosis is poorly understood. In fact, it is not even known if the normal fate of oocytes is apoptosis (survival signals are then of utmost importance to permit growth initiation) or growth (death signals then determine the numbers of follicles initiating growth). The answer to that question may vary with the follicle type. Within the reserves of primordial follicles, the high expression of proteins such as TNF $\alpha$ [16], TNF $\alpha$ receptor [71], myc [59], retinoblastoma protein [8], Fas/Apol [112] may indicate that, for primordial follicles, the normal fate is cell death. However, it is puzzling that cell death within the primordial follicle population appears to be spread throughout reproductive life, particularly in primates. Survival factors have not yet been identi- 
fied. Within preantral follicles, the opposite answer may be valid since the extent of apoptosis is far more limited than in primordial follicles. With the development of in vitro cultures of preantral follicles in rodents, significant information regarding compounds modulating apoptosis was obtained. A pro-apoptotic (TGF $\beta$ at $10 \mathrm{ng} / \mathrm{mL}$ ) and two anti-apoptotic (FGF and EGF at $50 \mathrm{ng} / \mathrm{mL}$ ) growth factors for preantral follicles were identified $[33,111]$. Whether or not they work by acting directly on the oocyte has not been established. While demonstrating their mechanism of action may be difficult because oocytes isolated from surrounding somatic cells survive and grow poorly, it should be remembered that, in male gonocytes, TGF $\beta 1$ and $\beta 2$ have been shown to be pro-apoptotic [74] while FGF appears to be anti-apoptotic [104]. Interestingly, when preantral follicles are cultured in vitro individually, very few of them become apoptotic [19]. In contrast, when two such follicles are cultured in contact in the same culture well, one of them displays a reduced growth rate, ultimately leading to death [89]. The compounds involved in these between follicle interactions remain to be identified.

\section{AUTOCRINE AND PARACRINE REGULATIONS BETWEEN THE OOCYTE AND GRANULOSA CELLS INVOLVED IN THE DEVELOPMENT OF THE OOCYTE'S ABILITY TO RESUME MEIOSIS}

Regarding the links between the amounts of steroids in follicular fluid and the ability of the oocyte to resume meiosis to reach the metaphase II stage, all available data have been obtained in humans undergoing ovarian stimulation and following hCG administration. Owing to the pharmacological amounts of hormones used and to the heterogeneity of the follicular cohort generated, they should therefore be considered with caution. Most reports agree that follicular fluids which contain immature (i.e. not having undergone germinal vesicle breakdown - GVBD) oocytes usually contain lower amounts of oestradiol than those containing metaphase II oocytes $[2,6,54]$. There are no identical data available in other models such as farm animals. In one of the above studies, the follicular fluid concentrations of EGF and IGF1 were also compared between follicles yielding mature and immature oocytes [2], demonstrating similar amounts of these growth factors in the two types of follicular fluids. This claim should be viewed with caution because assessment of EGF concentrations in follicular fluid is hampered by the presence of EGF binding compounds and also because IGF binding proteins, which are the key factor affecting IGF1 bioactivity, were not measured in the above study.

The role of steroids on nuclear maturation was also explored by using experimental alterations of steroidogenesis (administration of inhibitors of steroidogenesis) or by studying patients genetically deficient in specific steroidogenic enzymes. In primates [118], administration of an aromatase inhibitor during the mid follicular phase produced a drop in oestradiol and a rise in testosterone outputs by the maturing follicle. This altered steroidal environment markedly reduced the proportion of oocytes reaching the metaphase II stage. This observation is supported by the findings obtained in sheep [75] where follicles were cultured for $24 \mathrm{~h}$ in the presence of an inhibitor of $17 \alpha$ hydroxylase. Oocytes contained in such follicles could undergo GVBD but were blocked before or at the metaphase I stage. The limitation of such approaches is, however, that they do not identify the steroids which are of key importance (low oestradiol, varying amounts of testosterone or their ratio). Interestingly, a recent study using an inhibitor of progesterone synthesis, epostane [91] did not demonstrate any effect of withdrawing progesterone on oocyte maturation in primates. Overall, these pharmacological approaches may suggest that the ratio be- 
tween specific steroids may be more important than the actual amounts of these steroids. In any case, steroids do not appear to be a strict prerequisite for nuclear maturation as there is evidence that patients genetically deficient in $17 \alpha$ hydroxylase [80] or 17-20 desmolase [78] can successfully produce mature oocytes after administration of exogenous gonadotrophins despite very low amounts of androgens + oestrogens (17-20 desmolase) or oestrogens ( $17 \alpha$ hydroxylase) in follicular fluid. Along the same line, the observation of a patient with Laron syndrome [25] who had minimal IGF1 levels and managed to develop mature oocytes following administration of exogenous gonadotrophins also demonstrates that IGF1 is not a prerequisite for successful maturation of the oocyte.

Most of the solid information on the interactions between follicular products and nuclear maturation has been obtained in vitro by supplementation of IVM culture media with specific steroids, growth factors or proteins. For example, a very clear inhibitory effect of testosterone on the nuclear status of the oocyte after $18 \mathrm{~h}$ of culture has been reported in mice [1]. This effect appeared to be dose dependant and could also be demonstrated on denuded oocytes. Although such an effect appears clear cut, no confirmatory studies have been conducted in other species including domestic animals. Epidermal growth factor (EGF/TGF $\alpha$ ) is the growth factor for which a major effect on nuclear maturation of most species has been demonstrated. In mice $[21,26]$, cattle [44, $51,62,63]$, pig $[20,83]$ and primates [39], EGF/TGF $\alpha$ appears to have stimulatory effects on GVBD and/or on the percentage of oocytes reaching the metaphase II stage. Because the information on the amounts of EGF present in follicular fluid of these species is not solid, it is impossible to state whether the amounts used are actually physiological. It is also unclear if EGF/TGF $\alpha$ has the same potency on denuded oocytes since contradictory reports exist in mice [21, 26]. There is a large consensus on the lack of effects of IGF1 on resumption of meiosis (mice: Downs [27]; cattle: Lorenzo et al. [63]; pig: Reed et al. [83]). Interestingly, as regards TGF $\beta$, effects ranging from stimulatory [35] or null [27, 100] have been described in rodents, while inhibitory effects have been reported in swine [20]. Finally, the protein family which appears to have large effects on oocyte's nuclear maturation is the inhibin/activin/follistatin/MIS family of proteins. Stimulatory effects of inhibin $(10 \mathrm{ng} / \mathrm{mL})$ on nuclear maturation of cattle oocytes were reported recently [90]. This positive effect of inhibin is also suggested by data obtained in pigs by Miller et al. [69] who demonstrated higher amounts of immunoreactive follicular fluid $\alpha$ inhibin concentrations in follicles which contained GVBD oocytes compared to immature ones. Hence, it is puzzling that $\mathrm{O}$ et al. [73] failed to demonstrate such a positive effect in rats. In contrast, in the latter species, activin appears to have the ability to dose dependently induce GVBD $[53,85]$ although it is unclear whether it is also effective on denuded oocytes [53, 73]. By comparison, oocytes of large animals do not appear to be sensitive to activin (pig: Coskin and Liu [20]; cattle: Van Tol et al. [103]; Stock et al. [90]). As MIS appears to be preferentially produced by cumulus cells [4], it may play a role in resumption of meiosis since Takahashi et al. [93] and Ueno et al. [101] demonstrated in rats that MIS could dose dependantly inhibit GVBD and that this inhibition was independent of cumulus cells.

Another pair of proteins (c-kit and its ligand $\mathrm{KL}$ ) also appear to be relevant for the control of oocyte maturation since a recent report [52] claimed that c-kit expression when decreased was associated with an increased ability to resume meiosis. Furthermore, addition of KL to the culture medium of oocytes could also delay resumption of meiosis.

An attempt to summarize the effects of all these molecules on resumption of meiosis is presented in figure 2 . 


\section{AUTOCRINE AND PARACRINE REGULATIONS INVOLVED IN THE CYTOPLASMIC MATURATION OF THE OOCYTE}

Three approaches have been used to study the relationships between follicular products and oocyte cytoplasmic maturation. In the first one, the concentration of specific compounds in follicular fluid was related to the oocyte's ability to develop, mostly in human. Oocytes and follicular fluid were collected following ovarian stimulation and hCG administration. Regarding the relationships between specific steroids and quality of the oocyte, the numerous studies performed have generally found that oocytes enclosed by oestradiol-rich follicular fluid were of better quality $[6,13,36]$ although some other studies failed to confirm this finding [92, 94, 116]. In contrast, there is a general agreement between all studies for the lack of correlation between progesterone concentrations in follicular fluid and oocyte quality $[6,92,94$, 116]. The interpretation of these findings is further complicated by the observation that steroid binding proteins are present in follicular fluid (SHBG and CBP) and that the amounts of steroid binding proteins appear to be also related to the ability of the oocyte to develop following IVF [116]. Interestingly, the two studies which have related the amounts of gonadotrophins (FSH, LH) in follicular fluid to oocyte quality have shown that high concentrations of FSH [92] or hCG [58] are associated with an improved ability of the oocyte to develop following IVF. This may suggest that follicular vascularization (which regulates gonadotrophin delivery to follicles) may play a role in oocyte quality, a finding confirmed by the study of Itskovitz et al. [54] showing that prorenin concentration in follicular fluid can be related to the success of IVF. Only one study has related the amounts of growth factors in follicular fluid and oocyte quality. Artini et al. [2] could not relate the ability of the oocyte to fertilize with the follicular fluid concentrations of either IGF1 or EGF. Franchimont et al. [37] demonstrated a link between high follicular fluid inhibin and low aromatase inhibitor and an oocyte of good quality.

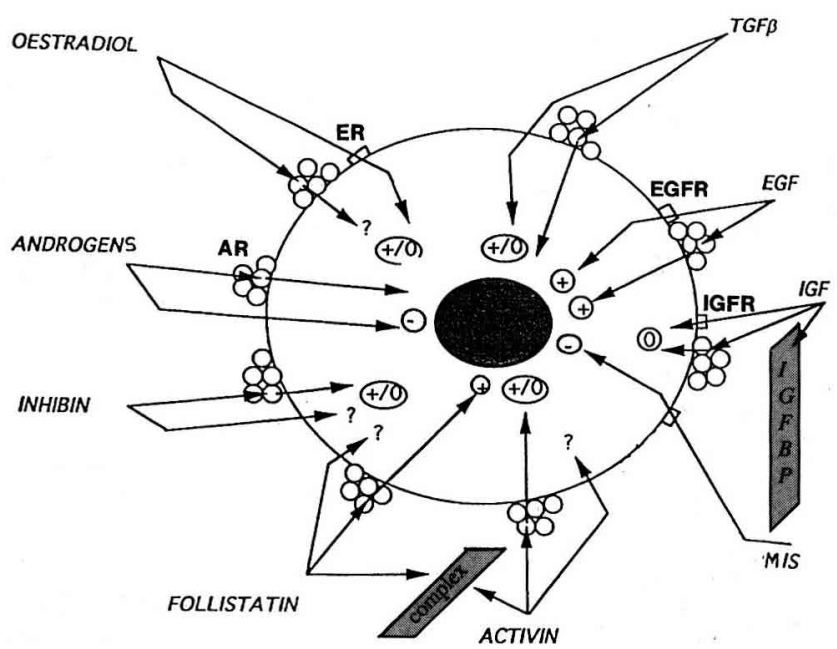

Figure 2. Molecules modulating oocyte nuclear maturation either directly (effects obtained on denuded oocytes) or via the surrounding cumulus cells ( $)$. Positive effects are indicated by $(+)$ while inhibitory effects are indicated by $(-)$. (0) is used when no clear effects were obtained. Receptors are indicated on the oocyte surface (AR: androgen receptor; ER: oestradiol receptor). 
However, because all this information was obtained at stages of maturation markedly different from that in domestic animal IVF, caution should be exercised before extrapolating these conclusions to cattle. In this species, only one study [45] has attempted to correlate blastocyst development with features of follicular fluid following analysis of individual oocyte/follicles. They showed that high progesterone was detrimental to oocyte quality while there was no relationship between amounts of oestradiol and IGF1 in follicular fluid and oocyte quality. We (Driancourt et al., unpublished results) have recently completed a study combining IVM/IVF/IVD of individual oocytes with the study of numerous follicular markers to extend these findings. Oocytes $(n=93)$ were grouped in three categories following IVD. Class A were oocytes which developed to the blastocyst stage. Classes B were oocytes which cleaved but did not reach the blastocyst stage. Class $\mathrm{C}$ were oocytes which did not cleave following IVF. The respective proportions of classes A, B and C were 40, 35 and $25 \%$. The main conclusions of this study were that: 1) there was no difference between class $\mathrm{A}$, class $\mathrm{B}$ and class $\mathrm{C}$ oocytes in the amounts of steroids (oestradiol, testosterone, progesterone) of their follicles of origin; 2) healthy follicles (as evidenced by high aromatase activity) contained more class A oocytes than atretic follicles; 3 ) high amounts of specific $\alpha$ inhibin forms could be found in follicular fluid containing class $A$ oocytes. In contrast, amounts of $\beta$ inhibin were identical in follicular fluid containing class A, B or C oocytes; and 4) numerous compounds (LH receptors, FSH receptors, EGF receptors, progesterone receptors, amounts of matrix metalloproteinases and of TIMP's in follicular fluid, etc.) could not be related to oocyte quality.

In the second one, pharmacological models in which follicular steroidogenesis is altered have been used to assess whether steroids may be involved in cytoplasmic maturation of the oocyte. Administration of an aromatase inhibitor [118] or of an inhi- bitor of $3 \beta$ hydroxysteroid deshydrogenase to primates during the mid follicular phase [91] did not alter follicle development but markedly reduced the ability of the oocyte to develop following fertilization. Both studies provide solid evidence that a proper steroid environment within the follicle is important for oocyte quality. The limit of these approaches is, however, that it is impossible to identify which steroids are important, because prevention of synthesis of a specific steroid results in accumulation of its precursors.

In the third one, in vitro approaches have been undertaken to test the physiological effects on oocyte quality of adding specific molecules to the maturation medium. This approach proved very fruitful to identify compounds which were stimulatory (EGF/TGF $\alpha$, inhibin/activin), inhibitory (androgens) or had no clear activity (IGF1/IGF2) to cytoplasmic maturation. The only steroid for which a clear effect has been observed is testosterone for which Andriesz and Trounson [1] demonstrated a dosedependant inhibitory effect on cytoplasmic maturation. Regarding growth factors, several studies have demonstrated a positive role of EGF on cytoplasmic maturation. Beneficial effects of addition of EGF/TGF $\alpha$ to the maturation medium were observed on cytoplasmic maturation of mice [21] or cattle $[55,61]$ oocytes. There is no general agreement on the effects of IGF1/IGF2 on cytoplasmic maturation. On the one hand Herrler et al. [46] found a beneficial effect while Carolan et al. [12] found no effect at all. Finally, neither TGF $\beta$ or FGF appear to have the ability to affect cytoplasmic maturation [55]. Interestingly, a recent report described a positive effect of inhibin or activin on cytoplasmic maturation [90]. Both compounds were active and there was no synergy between inhibin and activin. This finding is, however, difficult to reconcile with the observations that follicular fluid (inhibin/activin rich medium) has the same effect on cytoplasmic maturation as serum (inhibin/activin poor medium) $[61,88]$. A summary of these effects is presented in figure 3 . 


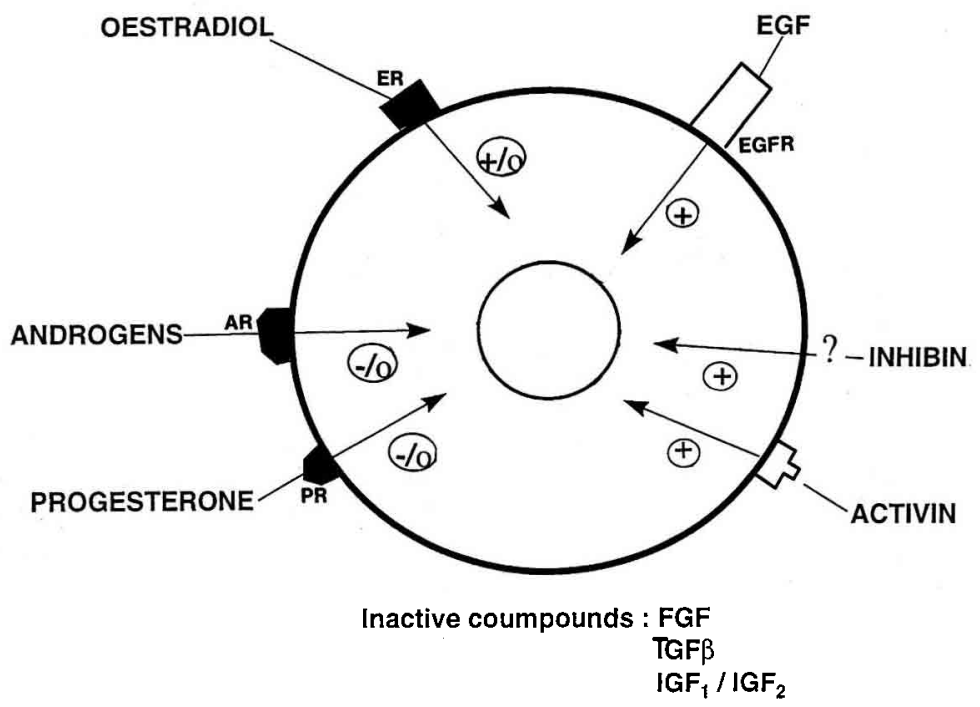

Figure 3. Molecules modulating cytoplasmic maturation of the oocyte. Positive effects and inhibitory effects are noted $(+)$ and $(-)$, respectively.

\section{CONCLUSIONS}

Despite the large amount of literature searched in writing this review, our understanding of most of the key phases of oocyte development is far from complete. Significant progress requires that several questions are addressed.

1) Are all oocytes similar? Heterogeneity within the oocyte population is obvious. What causes this heterogeneity and whether it tends to change with ageing also needs further investigation. Is the time of oocyte formation and of primordial follicle formation important for the fate (growth or apoptosis) of the follicle?

2) Amongst the compounds already shown to affect oocyte quality, which are of critical importance and which are only of limited importance?

3) How does follicular atresia affect oocyte quality? Are oocytes in atretic follicles better [5] or worse (Driancourt et al., unpublished results) than those originating from healthy follicles?
4) What are the mRNAs or proteins produced in the oocytes at the stage of follicular growth when the oocyte gains the ability to undergo nuclear or cytoplasmic maturation? Differential display techniques will be helpful to address this problem.

5) What are the mRNAs still actively produced in the oocytes on the day before ovulation (in vivo maturation) or during IVM (in vitro maturation)? How do they differ between the in vivo and in vitro groups? Again in vitro transcription techniques or differential display could be useful.

Major improvements in the IVM/IVF/IVD systems would surely benefit from clear answers to the above questions.

\section{ACKNOWLEDGEMENTS}

Stimulating discussions with our collegues A. Gougeon (Inserm, Lyon) and P. Mermillod, Y. Cognié., G. Baril (Inra, Nouzilly) were helpful in writing this review. 


\section{REFERENCES}

[1] Andriesz C., Trounson A., The effect of testosterone on the maturation and developmental capacity of murine oocytes in vitro, Hum. Reprod. 10 (1995) 2377-2381.

[2] Artini P.G., Battaglia C., Dambrogio G., Barreca A., Droghni F., Volpe A., Genazzani A.R., Relationship between human oocyte maturity, fertilization and follicular fluid growth factors, Hum. Reprod. 9 (1994) 902-906.

[3] Baker J., Hardy M.P., Zhou J., Bondy C., Lupu F., Bellvé A.R., Efstratiadis A., Effects of an IgF1 gene mull nutation on mouse reproduction, Mol. Endocr. 10 (1996) 903-918.

[4] Bézard J., Vigier B., Tran D., Mauléon P., Josso N., Immunocytochemical study of anti Müllerian hormone in sheep ovarian follicles during fetal and postnatal development, J. Reprod. Fert. 80 (1987) 509-516.

[5] Blondin P., Sirard M.A., Oocyte and follicular morphology as determining characteristics for developmental competence in bovine oocytes, Mol. Reprod. Dev. 41 (1995) 54-62.

[6] Botero Ruiz W., Laufer N., de Cherney A.H., Polan M.L., Haseltine F.P., Behrman H.R., The relationship between follicular fluid steroid concentration and successful fertilization of human oocytes in vitro, Fert. Ster. 41 (1984) 820-826.

[7] Braw Tal, Expression of mRNA for follistatin and inhibin/activin subunits during follicular growth and atresia, J. Mol. Endocr. 13 (1994) 253-264.

[8] Bukowsky A., Candle M.R., Keenan J.A., Wimalasena J., Foster J.S., Van Meter S.E., Quantitative evaluation of the cell cycle related retinoblastoma protein and localization of Thy1 differentiation protein and macrophages during follicular development and atresia, Biol. Reprod. 52 (1995) 776-792.

[9] Byskov A.G., Follicular atresia, in: Jones R.E. (Ed.), The Vertebrate Ovary, Plenum Press, New York, 1979, pp. 533-554.

[10] Cameron V.A., Nishimura E., Mathews L.S., Lewis K.A., Sawchenko P.E., Vale W.W., Hybridization histochemical localization of activin receptor subtypes in rat brain, pituitary, ovary and testis, Endocrinology 134 (1994) 799-808.

[11] Canipari R., Palombi F., Riminucci M., Mangia F., Early programming of maturation competence in mouse organogenesis, Dev. Biol. 102 (1984) 519-524.

[12] Carolan C., Lonergan P., Monget P., Mermillod P., Role of insulin family of growth factors in bovine oocyte maturation (IVM) and embryo development in vitro, J. Reprod. Fert., Abst. Series 15 (1995) 211.
[13] Carson R.S., Trounson A.O., Findlay I.K., Successful fertilisation of human oocytes in vitro: concentration of oestradiol $17 \beta$, progesterone and androstenedione in the antral fluid of donor follicles, J. Clin. Endocr. Metab. 55 (1982) 798-803.

[14] Channing C.P., Bae I., Stone S.L., Anderson L.D., Edelson S., Fowler S.C., Porcine granulosa and cumulus cells properties. LH/hCG receptors, ability to secrete progesterone and ability to respond to $\mathrm{LH}$, Mol. Cell Endocr. 22 (1981) 359-370.

[15] Chegini N., Flanders K.C., Presence of transforming growth factor $\beta$ and their selective localisation in human ovarian tissue of various reproductive stages, Endocrinology 130 (1992) 1707-1715.

[16] Chen H.L., Marcinkiewicz J.L., SanchoTello M., Hunt J.S., Terranova P.F., Tumor necrosis factor $\alpha$ gene expression in mouse oocytes and follicle cells, Biol. Reprod. 48 (1993) 707-714.

[17] Chia C.M., Winston R.M., Handyside A.H., EGF, TGF-alpha and EGFR expression in human preimplantation embryos, Development 121 (1995) 299-307.

[18] Cohen G.M., Caspases: the executioners of apoptosis, Biochem. J. 326 (1997) 1-16.

[19] Cortvindt R., Smitz J., Van Steirteghem A.C., In vitro maturation, fertilization and embryo development of immature oocytes from early preantral follicles from prepuberal mice in a simplified culture system, Human Reprod. 11 (1996) 2656-2666.

[20] Coskun S., Lin Y.C., Effects of transforming growth factors and activin $A$ on in vitro porcine oocyte maturation, Mol. Reprod. Dev. 38 (1994) 153-159.

[21] Das K., Tagatz G.E., Stout L.E., Phipps W.R., Hensleigh H.C., Leung B.S., Direct positive effect of epidermal growth factor on the cytoplasmic maturation of mouse and human oocytes, Fert. Steril. 55 (1991) 1000-1004.

[22] Davis G.H., McEwan J.C., Fennessy P.F., Dodds K.G., Farquhar P.A., Evidence for the presence of a major gene influencing ovulation rate on the $\mathrm{X}$ chromosome of sheep, Biol. Reprod. 44 (1991) 620-624.

[23] Davis G.H., McEwan J.C., Fennessy P.F., Dodds K.G., McNatty K.P., O W.S., Infertility due to bilateral ovarian hypoplasia in sheep homozygous for the inverdale prolificacy gene located on the X chromosome, Biol. Reprod. 46 (1992) 636-640.

[24] Dong J., Albertini D.F., Nishimori K., Kumar T.R., Lu N., Matzuk M.M., Growth differentiation factor-9 is required during early folliculogenesis, Nature 383 (1996) 531-533.

[25] Dor J., Benshlomo I., Lunenfeld B., Pariente C., Leyran D., Karasik A., Seppala M., Mashiach S., Insulin-like growth factor (IGF1) may not be essential for ovarian follicular development. Evidence from IGF1 deficiency, J. Clin. Endocr. Metab. 74 (1992) 539-542. 
[26] Downs S.A., Daniel S.A.J., Eppig J.J., Induction of maturation in cumulus cell-enclosed mouse oocytes by follicle stimulating hormone and epidermal growth factor: evidence for a positive stimulus of somatic cell origin, J. Exp. Zool. 245 (1988) 86-96.

[27] Downs S.M., Specificity of epidermal growth factor action on maturation on the murine oocyte and cumulus oophorus in vitro, Biol. Reprod. 41 (1989) 371-379.

[28] Driancourt M.A., Gougeon A., Folliculogenèse, in: Hamamah S., Menezo Y. (Eds.), De l'ovocyte à l'embryon, Masson, Paris, 1998 (in press).

[29] Driancourt M.A., Cahil L.P., Bindon B.M., Ovarian follicular populations and preovulatory enlargement in Booroola and control Merino ewes, J. Reprod. Fert. 73 (1985) 93-103.

[30] Driancourt M.A., Gougeon A., Royère D., Thibault C., La fonction ovarienne, in: Thibault C., Levasseur M.C. (Eds.), La reproduction chez les mammiferes et chez l'homme, Ellipses, 1991.

[31] Driancourt M.A., Guet P., Magallon T., Follicular fluid from dominant sheep follicles contains a protein $(90 \mathrm{kDa}, \mathrm{pI}-8)$ which is involved in the control of aromatase activity, (1998) (submitted).

[32] Dufour J., Cahill L.P., Mauléon P., Short and long term effects of hypophysectomy and unilateral ovariectomy on ovarian follicular populations in sheep, J. Reprod. Fert. 57 (1979) 301-309.

[33] Eppig J.J., O'Brien M.J., Development in vitro of mouse oocytes from primordial follicles, Biol Reprod 54 (1996) 197-207.

[34] Fair T., Hyttel P., Greve T., Bovine oocyte diameter in relation of maturational competence and transcriptional activity, Mol. Reprod. Dev. 42 (1996) 437-442.

[35] Feng P., Catt K.J., Knecht M., Transforming growth factor beta stimulates meiotic maturation of the rat oocyte, Endocrinology 122 (1988) 181-186.

[36] Fishel S.B., Edwards R.G., Weilters D.E., Follicular steroids as a prognosticator of successful fertilization of human oocytes in vitro, J. Endocr. 99 (1983) 335-344.

[37] Franchimont P., Hazee-Hagelstein M.T., Charlet Renard C., Jaspar J.M., Hazout A., Salat Baroux J., Schatz B., Demerlé F., Correlation between follicular fluid content and the results of in vitro fertilization and embryo transfer. II Inhibin and aromatase inhibitor activity, J. Clin. Endocr. Metab. 71 (1990) 748-754.

[38] Fuhrer F., Mayr B., Schellander K., Kalat M., Schleger W., Maturation competence and chromatin behaviour in growing and fully grown cattle oocytes, J. Vet. Med. 36 (1989) 285-291.

[39] Gomez E., Tarin J.J., Pellicer A., Oocyte maturation in humans: the role of gonadotropins and growth factors, Fert. Ster. 60 (1993) 40-46.

[40] Gospodarowicz D., Bialecki H., Fibroblast and epidermal growth factors are mitogenic agents for cultured granulosa cells of rodent, porcine and human origin, Endocrinology 104 (1979) 757-764.

[41] Gougeon A., Regulation of ovarian follicular development in primates: facts and hypotheses, Endocr. Rev. 17 (1996) 121-156.

[42] Gougeon A., Ecochard R., Thalabard J.C., Age related changes in the population of human ovarian follicles: increase in the disappearance rate of non growing and early growing follicles in aging women, Biol. Reprod. 50 (1994) 653-663.

[43] Hanrahan J.P., Evidence for single gene effects on ovulation rate in the Cambridge and Belclare breeds, in: Elsen J.M., Bodin L., Thimonier J. (Eds.), Major Genes for Reproduction in Sheep, Inra Editions, 1990, pp. 93-104.

[44] Harper K.M., Brackett B.G., Bovine blastocyst development after in vitro maturation in a defined medium with epidermal growth factor and low concentrations of gonadotropins, Biol. Reprod. 48 (1993) 409-416.

[45] Hazeleger N.L., Hill D.J., Stubbings R.B., Walton J.S., Relationship of morphology and follicular fluid environment of bovine oocytes of their developmental potential in vitro, Theriogenology 43 (1995) 509-522.

[46] Herrler A., Lucas Hahn A., Niemann H., Effects of insulin like growth factor 1 on in vitro production of bovine embryos, Theriogenology 37 (1992) 1213-1224.

[47] Hirshfield A.N., Patterns of 3H-thymidine incorporation differ in immature rats and mature, cycling rats, Biol. Reprod. 34 (1986) 229-235.

[48] Hsu S.Y., Kubo M., Chun S.Y., Haluska F.G., Honsman De., Hsueh A.J.W., Wilms tumor protein WTl as an ovarian transcription factor: decreases in expression during follicle development and repression of inhibin $\alpha$ gene promoter, Mol. Endocr. 9 (1995) 1356-1366.

[49] Huang E.J., Manova K., Packer A.I., Sanchez S., Bachvarova R.F., Besmer P., The murine Steel panda mutation affects kit ligand expression and growth of early ovarian follicles, Dev. Biol. 157 (1993) 100-109.

[50] Hulshof S.C.J., Figueiredo J.R., Beckers J., Bevers M.M., Vanderstichele H., Van den Hurk R., Bovine preantral follicles and activin: Immunohistochemistry for activin and activin receptor and the effect of bovine activin $A$ in vitro, Theriogenology 48 (1997) 133-142.

[51] Im K.S., Park K.W., Effects of epidermal growth factor on maturation, fertilization and development of bovine follicular oocytes, Theriogenology 44 (1995) 209-216.

[52] Ismail R.S., Dube M., Vanderhyden B.C., Hormonally regulated expression and alternative splicing of kit ligand may regulate kit-induced inhibition of meiosis in rat oocytes, Dev. Biol. 184 (1997) 333-342. 
[53] Itoh M., Igarashi M., Yamada K., Hasegawa Y., Seki M., Eto Y., Shibai H., Activin A stimulates meiotic maturation of the rat oocyte in vitro, Biochem. Biophys. Res. Com. 166 (1990) 1479-1484.

[54] Itskovitz J., Rubattu S., Rosenvwaks Z., Liu H.C., Sealey J.E., Relationship of follicular fluid prorenin to oocyte maturation, steroid levels and outcome of in vitro fertilization, J. Clin. Endocr. Metab. 72 (1991) 165-171.

[55] Kobayashi K., Yamashita S., Hoshi H., Influence of epidermal growth factor and transforming growth factor $\alpha$ on in vitro maturation of cumulus cell-enclosed bovine oocytes in a defined medium, J. Reprod. Fert. 100 (1994) 439-446.

[56] Kumar T.R., Wang Y., Lu N.F., Matzuk M.M., Follicle stimulating hormone is required for ovarian follicle maturation but not male fertility, Nat. Genet. 15 (1997) 201-204.

[57] Kuroda H., Terada N., Nakayama H., Matsumoto K., Kitamura Y., Infertility due to growth arrest of ovarian follicles in SI/Slt mice, Dev. Biol. 126 (1988) 71-79.

[58] Laufer N., Botero Ruiz W., De Cherney A.H. Haseltine F., Polan M.L., Behrman H.R., Gonadotropin and prolactin levels in follicular fluid of human ova successfully fertilized in vitro, J. Clin. Endocr. Metab. 58 (1984) 430-434.

[59] Li S.W., Maruo T., Ladinesllave C.A. Hondo H., Mochizuki M., Stage limited expression of myc oncoprotein in the human ovary during follicular growth, regression and atresia, Endocrine J. 41 (1994) 83-92.

[60] Lintern Moore S., Moore G.P.M., The initiation of follicle and oocyte growth in the mouse ovary, Biol. Reprod. 20 (1979) 773-778.

[61] Lonergan P., Monaghan P., Rizos D., Boland M.P., Gordon I., Effect of follicle size on bovine oocyte quality and developmental competence following maturation, fertilization and culture in vitro, Mol. Reprod. Dev. 37 (1994) $48-53$.

[62] Lonergan P., Carolan C., Van Langendonckt A., Donnay I., Khatir H., Mermillod P., Role of epidermal growth factor in bovine oocyte maturation and preimplantation embryo development in vitro, Biol. Reprod. 54 (1996) 1420-1429.

[63] Lorenzo P.L., Illera M.J., Illera J.C., Illera M., Role of EGF, IGF1, sera and cumulus cells on maturation in vitro of bovine oocytes, Theriogenology 44 (1995) 109-118.

[64] Manova K., Nocka K., Besmer P., Bachvarova R.F., Gonadal expression of c-kit encoded at the $\mathrm{W}$ locus in the mouse, Development 110 (1990) 1057-1069.

[65] Manova K., Huang E.J., Angeles M., Deleon V., Sanchez S., Pronovost S.M., Besmer P., Bachvarova R.F., The expression pattern of the c-kit ligand in gonads of mice supports a role for the c-kit receptor in oocyte growth and in proliferation of spermatogonia, Dev. Biol. 157 (1993) 85-99.
[66] Marcinkewicz J.L., Krishna A., Cheung C.M.Y., Terranova P.F., Oocytic tumor necrosis factor alpha: localization in the neonatal ovary and throughout follicular development in the adult rat, Biol. Reprod. 50 (1994) 1251-1260.

[67] Mariana J.C., Analyse biométrique de l'index de marquage des cellules folliculenses et de la taille des ovocytes de follicules primordiaux d'ovarie de ratte adulte cyclique, Ann. Biol. Anim. Biochem. Biophys. 18 (1978) 1333-1342.

[68] Mc Caffery C., McEvoy T.G., Diskin M.G., Gwazdanskas F.C., Kane M.T., Sreenan J.M., Successful co-culture of $1-4$ cell cattle ova to the morula or blastocyst stage, J. Reprod. Fert. 91 (1991) 119-124.

[69] Miller K.F., Xie S., Pope W.F., Immunoreactive inhibin in follicular fluid is related to meiotic stage of the oocyte during final maturation of the porcine follicle, Mol. Reprod. Dev. 28 (1991) 35-39.

[70] Motro B.,Bernstein A., Dynamic changes in ovarian c-kit and Steel expression during the estrous reproductive cycle, Dev. Dynamics 197 (1993) 69-79.

[71] Naz R.K., Zhu X., Menge A.C., Expression of tumor necrosis $\alpha$ and its receptors type $I$ and type II in human oocytes, Mol. Reprod. Dev. 47 (1997) 127-133.

[72] Nuttinck F., Collette L., Massip A., Dessy F., Histologic and autoradiographic study of the in vitro effects of $\mathrm{FGF} 2$ and $\mathrm{FSH}$ on isolated bovine preantral follicles: preliminary investigation, Theriogenology 45 (1996) 1235-1245.

[73] OW.S., Robertson D.M., de Kretser D.M., Inhibin as an oocyte meiotic inhibitor, Mol. Cell Endocr. 62 (1989) 307-311.

[74] Olaso R., Pairault C., Boulogne B., Durand P., Habert R., Transforming growth factor B1 and B2 reduce the number of gonocytes by increasing apoptosis, Endocrinology 139 (1998) 733-740.

[75] Osborn J.C., Moor R.M., The role of steroid signals in the maturation of mammalian oocytes, J. St. Biochem. 19 (1983) 133-137.

[76] Packer A.I., Hon Y.C., Besmer P., Bachvarova $R . F .$, The ligand of the c-kit receptor promotes oovcyte growth, Dev. Biol. 161 (1994) 194-205.

[77] Pavlok A., Lucas-Hahn A., Niemann H., Fertilization and developmental competence of bovine oocytes derived from different categories of antral follicles, Mol. Reprod. Dev. 31 (1992) 63-67.

[78] Pellicer A., Miro F., Sampaio M., Gomez E., Bonilla Musoles F.M., In vitro fertilization as a diagnostic and therapeutic tool in a patient with partial 17, 20 desmolase deficiency, Fert. Ster. 55 (1991) 970-974.

[79] Peng X.R., Hsueh A.S.W., Lapolt P.S. Bjersing I, Ny T., Localisation of luteinizing hormone receptor messenger ribonucleic acid expression in ovarian cell types during follicular development and ovulation, Endocrinology 129 (1991) 3200-3207. 
[80] Rabinovici J., Blankstein J., Goldman B., Rudak E., Dor Y., Pariente C., Geier A., Lunenfeld B., Mashiach S., In vitro fertilization and primary embryonic cleavage are possible in $17 \alpha$ hydroxylase deficiency despite extremely low intrafollicular 173 oestradiol, J. Clin. Endocr. Metab. 68 (1989) 693-700.

[81] Rappolee D.A., Brenner C.A., Schultz R., Mark D., Werb Z., Developmental expression of PDGF, TGF- $\alpha$ and TGF- $\beta$ genes in preimplantation mouse embryos, Science 241 (1988) $1823-1825$

[82] Ratts V.S., Flaws J.A., Kolp R., Sorenson C.M., Tilly J.M., Ablation of bcl 2 gene expression decreases the number of oocytes and primordial follicles established in the post natal female mouse gonad, Endocrinology 136 (1995) 3665-3668.

[83] Reed M.L, Estrada J.L., Illera M.J., Petters R.M., Effects of epidermal growth factor, insulin like growth factor 1 and dialyzed porcine follicular fluid on porcine oocyte maturation in vitro, $\mathbf{J}$. Exp. Zool. 266 (1993) 74-78.

[84] Roy S.K., Kole A.R., Transforming growth factor $\beta$ receptor type II expression in the hamster ovary: cellular site(s), biochemical properties and hormonal regulation, Endocrinology 136 (1995) 4610-4620.

[85] Sadatsuki M., Tsutsumi O., Yamada R., Muramatsu M., Taketani Y., Local regulatory effects of Activin A and follistatin on meiotic maturation of rat oocytes, Biochem. Biophys. Res. Com. 196 (1991) 388-395.

[86] Schotanus K., Hage W.J., Spek E.R., Bevers M.M., Van den Hurk R., Viability aspects of isolated bovine preantral follicles, Proc. 13th ICAR, Sydney, 1996, pp. 7-27.

[87] Singh B., Armstrong D.T., Transforming growth factor $\alpha$ gene expression and peptide localisation in porcine ovarian follicles, Biol. Reprod. 53 (1995) 1429-1435.

[88] Sirard M.A., Roy F., Patrisck B., Mermillod P., Guilbault L.A., Origin of follicular fluid added to the media during bovine IMV influences embryonic development, Theriogenology 44 (1995) 85-94.

[89] Spears N., de Brain J.P., Gosden R.G., The establishment of follicular dominance in co-cultured mouse ovarian follicles, J. Reprod. Fert. 106 (1996) 1-6.

[90] Stock A.E., Woodruff T.K., Smith L.C., Effects of inhibin $\mathrm{A}$ and activin $\mathrm{A}$ during in vitro maturation of bovine oocytes in hormone and serum free medium, Biol. Reprod. 56 (1997) 1559-1564.

[91] Stouffer R.L., Brenner R.H., Hess D.L., Hibbert M.A., Wolf D.P., Zelinski Wooten M.B., Role of steroids in folliculogenesis: human and non human primate studies, in: Filicori M., Flamigni C. (Eds.), The Ovary: Regulation, Dysfunction and Treatment, Elsevier, 1996, pp. 35-40.
[92] Suchanek E., Simunic V., Juretic D., Grizely V., Follicular fluid contents of hyaluronic acid, follicle stimulating hormone and steroids relative to the success of in vitro fertilisation of human oocytes, Fert. Ster. 62 (1994) 347-352.

[93] Takahashi M., Koide S.S., Donahoe P.K., Mullerian inhibiting substance as oocyte meiosis inhibitor, Mol. Cell. Endocr. 47 (1986) 225-234.

[94] Tarlatzis B.C., Pazaitou K., Bili H., Bontis J., Papadimas J., Lagos S., Spanos E., Mantalenakis S., Growth hormone, oestradiol, progesterone and testosterone concentrations in follicular fluid after ovarian stimulation with various regimes for assisted reproduction, Hum. Reprod. 8 (1993) 1612-1616.

[95] Teissier M.P., Monget P., Monniaux D., Durand $P$., Changes in insulin-like growth factor-II/mannose-6-phosphate receptor during growth and atresia of ovine ovarian follicles, Biol. Reprod. 50 (1994) 111-119.

[96] Telfer E., Johnson K.A., Eppig J.J., Expression of cytochrome $\mathrm{p}-450$ aromatase mRNA during murine follicular development in vitro and in vivo, J. Reprod. Fert. Abstr. Series 9 (1992) 17.

[97] Tilly J.L., Apoptosis, cell death genes and the fate of the mammalian egg, J. Reprod. Fert. Abstr. Series 20 (1997) 52.

[98] Tisdall D.J., Hudson N., Smith P., McNatty K.P., Localization of ovine follistatin and $\alpha$ and $B A$ inhibin mRNA in the sheep ovary during the oestrous cycle, J. Mol. Endocr. 12 (1994) 181-193.

[99] Tisdall D.J., Quirke L.D., Smith P., McNatty K.P., Expression of the ovine stem cell factor gene during folliculogenesis in late fetal and adult ovaries, J. Mol. Endocr. 18 (1997) 127-135.

[100] Tsafriri A., Vale W., Hsueh A.J.W., Effects of transforming growth factors and inhibin related proteins on rat preovulatory graapian follicles in vitro, Endocrinology 125 (1989) 1857-1862.

[101] Ueno S., Manganaro T.F., Donahoe P.K. Human recombinant mullerian inhibiting substance inhibition of rat oocyte meiosis is reversed by epidermal growth factor in vitro, Endocrinology 123 (1988) 1652-1659.

[102] Ueno S., Kuroda T., Manganaro T.F., Donahoe P.K., Mullerian inhibiting substance in the adult rat ovary during various stages of the oestrous cycle, Endocrinology 125 (1989) 1060-1066.

[103] Van Tol H.T.A., de Loos F.A.M., Vanderstichele H.M.J., Bevers M.M., Bovine activin A does not affect the in vitro maturation of bovine oocytes, Theriogenology 41 (1994) 673-679.

[104] Van Dissel-Emiliani F.M.F., De Boer-Brouwer M., De Rooij D.G., Effect of fibroblast growth factor 2 on Sertoli cells and gonocytes in coculture during the perinatal period, Endocrinology 137 (1996) 647-654. 
[105] Van Vezel I., Unapathysivain K., Tilley W.D., Rodgers R.J., Immunohistochemical localisation of fibroblast growth factor in bovine ovarian follicles, Mol. Cell Endocr. 115 (1995) 133-140.

[106] Vanderhyden B.C., Telfer E.E., Eppig J.J., Mouse oocytes promote proliferation of granulosa cells from preantral and antral follicles in vitro, Biol. Reprod. 46 (1992) 1196-1204.

[107] Vanderhyden B.C., Cohen J.M., Morley P., Mouse oocytes regulate granulosa cell steroidogenesis, Endocrinology 133 (1993) 423-426.

[108] Villa P., Kaufman S.H., Earnshaw W.C., Caspases and caspases inhibitors, ITBS 22 (1997) 388-393.

[109] Wandji S.A., Pelletier G., Sirard M.A., Ontogeny and cellular localization of ${ }^{125}$ I labelled basic fibroblast growth factor and epidermal growth factor binding sites in ovaries from bovine fetuses and neonatal calves, Biol. Reprod. 47 (1992) 807-813.

[110] Wandji S.A., Pelletier G., Sirard M.A., Ontogeny and cellular localization of ${ }^{125}$ I labelled insulin like growth factor $1, \mathrm{FSH}$ and hCG in ovaries from bovine fetuses and neonatal calves, Biol. Reprod. 47 (1992) 814-822.

[111] Wandji S.A., Srsen V., Voss A.K., Eppig J.J., Fortune J.E., Initiation in vitro of growth of bovine primordial follicles, Biol. Reprod. 55 (1996) 942-948.

[112] Watanabe-Fukinaga R., Brannan C.I., Itoh N., The cDNA structure, expression and chromosonal assignment of the Fas antigen, J. Immunol. 148 (1992) 1274-1279.

[113] Watson A.J., Hogan A., Halnel A., Wiemer K.E., Schultz G.A., Expression of growth factor ligand and receptor genes in the preimplantation bovine embryo, Mol. Reprod. Dev. 31 (1992) 87-95.

[114] Woodruff T.K., Krummen L., Chen S.A., Lyon R., Hansen S.E., Deguzman G., Covello R.,
Mather J., Cossum P., Pharmacokinetic profile of recombinant human Inhibin A and Activin $A$ in the immature rat. II. Tissue distribution of ${ }^{125}$ I Inhibin A and ${ }^{125}$ I Activin A in immature female and male rats, Endocrinology 132 (1993) 725-734.

[115] Wu T.C.J., Wang L., Wan Y.J.Y., Expression of estrogen receptor gene in mouse oocyte and during embryogenesis, Mol. Reprod. Dev. 33 (1992) 407-412.

[116] Yding-Andersen C., Levels of steroid binding proteins and steroids in human preovulatory follicular fluid and serum as predictors of success in in vitro fertilisation-embryo transfer treatment, J. Clin. Endocr. Metab. 71 (1990) 1375-1381.

[117] Yoshida H., Takamura N., Kataoka H., Kunisada T., Okamura H., Mishikawa S.I., Stepwise requirement of c-kit tyrosine kinase in mouse ovarian follicle development, Dev. Biol. 184 (1997) 122-137.

[118] Zelinski Wooten M.B., Hess D.L, Baughman W.L., Molskness T.A., Wole D.P., Stouffer R.L., Administration of an aromatase inhibitor during the late follicular phase of gonadotropin treated cycles in rhesus monkeys: effects on follicle development, oocyte maturation and subsequent luteal function, J. Clin. Endocr. Metab. 76 (1993) 988-995.

[119] Zhong C., Ishimura K., Yoshinaga-Hirabayashi T., Fujita H., Kitawaki J., Osawa Y., Immunocytochemical study on the localisation of aromatase in the ovary of golden hamster, guinea pig and cow, Acta Histochem. Cytochem. 22 (1989) 501-507.

[120] Zoller L.C, Weisz J., A quantitative cytochemical study of glucose-6-phosphate dehydrogenase and 3BOHsteroid dehydrogenase activity in the membrana granulosa of the ovulable type of follicle of the rat, Histochemistry 62 (1979) 125-135. 